\title{
Effect of Aluminium Doping on Structural and Magnetic Properties of Ni-Zn Ferrite Nanoparticles
}

\author{
K. Vijaya Kumar1', D. Paramesh², P. Venkat Reddy² \\ ${ }^{1}$ Department of Physics, Jawaharlal Nehru Technological University Hyderabad College of Engineering, \\ Nachupally (Kondagattu), Karimnagar-Dist, Telangana State, India \\ ${ }^{2}$ Sreenidhi Institute of Science and Technology (Autonomous), Hyderabad, India

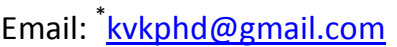

Received 1 June 2015; accepted 4 August 2015; published 7 August 2015

Copyright (C) 2015 by authors and Scientific Research Publishing Inc.

This work is licensed under the Creative Commons Attribution International License (CC BY). http://creativecommons.org/licenses/by/4.0/

(c) (i) Open Access

\begin{abstract}
Aluminium doped Ni-Zn ferrite nanoparticles of general formula of $\mathrm{Ni}_{0.5} \mathrm{Zn}_{0.5} \mathrm{Al}_{x} \mathrm{Fe}_{2-\mathrm{x}} \mathrm{O}_{4}(\mathrm{x}=\mathbf{0 . 0}, 0.2$, 0.4, 0.6, 0.8, 1.0, 1.2, 1.4, 1.6, 1.8, 2.0) have been synthesized by sol-gel auto combustion method and characterized using X-ray diffraction (XRD), scanning electron microscopy (SEM), energy dispersive X-ray (EDX), Fourier transform spectroscopy (FTIR) and vibrating sample magneto meter (VSM). XRD studies confirm that all compositions show single phase cubic spinel structure. The crystallite size was calculated using the Debye-Scherrer formula and found in the range of 17 - 52 $\mathrm{nm}$. The lattice parameter " $\mathrm{a}$ " is found to decrease with increasing $\mathrm{Al}^{3+}$ content. The SEM images clearly show the crystalline structure and EDX patterns confirm the compositional formation of the synthesized compositions. The results of FTIR analysis indicated that the functional groups of $\mathrm{Ni}$-Zn spinel ferrite were formed during the sol-gel synthesis process. The IR spectra showed two main absorption bands, the high frequency band $v_{1}$ around $600 \mathrm{~cm}^{-1}$ and the low frequency band $v_{2}$ around $400 \mathrm{~cm}^{-1}$ arising from tetrahedral $(A)$ and octahedral $(B)$ interstitial sites in the spinel lattice. As doping is increased the magnetic behavior is found to decrease and the composition $x=$ 2.0 ferrite appears to be exhibiting superparamagnetism as the coercive field and retentivity are found near zero.
\end{abstract}

\section{Keywords}

Al-Ni-Zn Ferrite Nanoparticles, XRD, EDX, SEM, FTIR, VSM

\footnotetext{
${ }^{*}$ Corresponding author.
}

How to cite this paper: Kumar, K.V., Paramesh, D. and Reddy, P.V. (2015) Effect of Aluminium Doping on Structural and Magnetic Properties of Ni-Zn Ferrite Nanoparticles. World Journal of Nano Science and Engineering, 5, 68-77. 


\section{Introduction}

Since few decades, the ferrites have attained a good position of economic, engineering and magnetic importance due to their excellent physical and chemical properties. Ferrites have a wide range of applications in microwave absorbance, number of electronic devices as radio, TV sets, integrated non-reciprocal circuits, high frequency transformers, memory core devices, rod antennas and telecommunication applications. Furthermore, they are used for gas and ethanol sensors. Due to wide range of applications, the different compositional substitutions into the ferrites have gained importance. The most common soft ferrites are Ni-Zn and Mn-Zn ferrites. The crystal structure of $\mathrm{Ni}-\mathrm{Zn}$ ferrites spinel configuration is based on a face centered cubic lattice of oxygen ions. The unit cell consists of eight formula units of the type $\left[\mathrm{ZnFe}_{1_{-x}}\right] \mathrm{A}\left[\mathrm{Ni}_{1_{-\mathrm{x}}} \mathrm{Fe}_{1_{+\mathrm{x}}}\right] \mathrm{BO}_{4}$, where $\mathrm{A}$ and $\mathrm{B}$ represent tetrahedral and octahedral sites, respectively [1]-[8]. They have a low coercivity and are called soft ferrites. The physical properties of such nanoferrites are highly sensitive to the method of preparation, grain size, chemical composition, sintering temperature, atmosphere, type of substituents and the distribution of cations among tetrahedral and octahedral sites [9]. The conventional methods for the preparation of ferrites have certain limitations such as long heating schedule at high temperatures, higher grain size, higher time consumption etc. The experimental conditions used in the preparation of these materials play an important role in the properties and the particle size of the ferrite nano particles produced. For this reason, a great variety of experimental methods have been used in the production of nano particles, like the sol-gel auto combustion technique. Among several synthesis methods including sol-gel auto-combustion [10], co-precipitation [11], hydrothermal [12], high-energy ball milling [13] and micro-emulsion [14] are developed to make nickel ferrite nano particles. Sol-gel auto combustion technique has many advantages over other methods such as the effect of minimal contamination, processing simplicity, low cost, high level of reactivity, easy control of the particle size and the efficiency of more homogeneous mixing of the component materials that lead to the formation of nanocrystallites.

Nickel-zinc ferrites are soft magnetic materials having low coercivity and high electrical resistivity, which makes them an excellent core material for power transformer in electronic and telecommunication applications [15]. Nickel and zinc have strong occupational preference for tetrahedral and octahedral sites respectively, which makes nickel ferrite a model inverse spinel and zinc ferrite a model normal one [16]. However, in Ni-Zn ferrites, the compositional variation can be resulted in the formation of mixed spinel structure, due to the redistribution of metal ions over the tetrahedral and octahedral sites, which can be drastically modified the ferrites properties [17] [18].

Aluminum substituted Ni-Co ferrites have high electrical resistivity, low eddy current losses, square nature of hysteresis loops, high stability and high value of saturation magnetization, hence they have enormous technological application over wide range of frequencies [19]. Recently, the diamagnetic substitution in mixed ferrites has received special attention. The role played by the substituents in modifying the physical properties of basic ferrites and the mechanism behind enhanced magnetic response is not widely studied. Fabrication of ferrite materials of high quality, low cost and low loss at high frequency for power applications is ever demanding. In this aspect, we have chosen $\mathrm{Al}$ doped $\mathrm{Ni}-\mathrm{Zn}$ ferrites with a composition of $\mathrm{Ni}_{0.5} \mathrm{Zn}_{0.5} \mathrm{Al}_{\mathrm{x}} \mathrm{Fe}_{2-\mathrm{x}} \mathrm{O}_{4}(\mathrm{x}=0.0,0.2,0.4,0.6$, $0.8,1.0,1.2,1.4,1.6,1.8,2.0)$ to obtain novel behavior of ferrites on the nanoscale.

\section{Experimental}

The starting materials were analytical grade (AR) with 99\% of purity. The materials were zinc nitrate hexahydrate- $\mathrm{Zn}\left(\mathrm{NO}_{3}\right)_{2} \cdot 6 \mathrm{H}_{2} \mathrm{O}(\mathrm{AR})$, nickel nitrate- $\mathrm{Ni}\left(\mathrm{NO}_{3}\right)_{2} \cdot 6 \mathrm{H}_{2} \mathrm{O}(\mathrm{AR})$, aluminium nitrate nonahydrate- $\mathrm{Al}\left(\mathrm{NO}_{3}\right)_{3} \cdot 9 \mathrm{H}_{2} \mathrm{O}$ (GR), Ferric Nitrate-Fe( $\left(\mathrm{NO}_{3}\right)_{3} \cdot 9 \mathrm{H}_{2} \mathrm{O}(\mathrm{GR})$ \& citric acid monohydrade- $\mathrm{C}_{6} \mathrm{H}_{8} \mathrm{O}_{7} \cdot \mathrm{H}_{2} \mathrm{O}(\mathrm{GR})$. Citric acid helps for the homogenous distribution and segregation of the metal ions. During water dehydration, it suppresses the precipitation of metal nitrates because it has electronegative oxygen atoms interacting with electropositive metal ions. Therefore, at a relative low temperature the precursors can form a homogenous single phase ferrite. The mixed solution was neutralized to $\mathrm{pH} 7$ by adding ammonia, it helps for the well formation of gel and improves the solubility of metal ions. Metal nitrates taken in the required stoichiometric ratio were dissolved in a optimum amount of distilled water and mixed together. Then the citric acid was added to the nitrate solution in 3:1 molar ratio. The analytical grade liquid ammonia was added drop by drop to the nitrate solution under constant stirring to maintain the $\mathrm{pH}$ value 7 . The resulting solution was constantly heated on the magnetic stirrer around $300^{\circ} \mathrm{C}$ to allow gel formation.

The resultant gel was kept in open air environment to remove the absorbed water [20] and the precursor powder was sintered under the constant heating conditions at $600^{\circ} \mathrm{C}$ for 5 hours to obtain the final product. The re- 
sultant powder was grinded into fine particles by an agate mortar and pestle. Finally, the fine power was pressed into pellets with the help of hydraulic press by applying the 5 tons pressure. The structural properties of samples was studied by Rigaku X-ray diffractometer (Rigaku Miniflex II) using the CuK radiation (wavelength $=1.5406$ $\AA$ ). Scanning electron microscopy (SEM) images were obtained using a TESCAN, MIRA II LMH microscope. The composition was determined by energy dispersive X-ray spectroscopy (EDX, Inca Oxford, attached to the SEM). FTIR analysis carried out including the magnetic properties by using vibrating sample magnetometer (EZ VSM model) at room temperature.

\section{Results and Discussions}

The XRD patterns of $\mathrm{Ni}_{0.5} \mathrm{Zn}_{0.5} \mathrm{Al}_{\mathrm{x}} \mathrm{Fe}_{2-\mathrm{x}} \mathrm{O}_{4}(\mathrm{x}=0.0,0.2,0.4,0.6,0.8,1.0,1.2,1.4,1.6,1.8,2.0)$ ferrite nanoparticles presented in Figure 1 confirmed that all the calcined samples at $600^{\circ} \mathrm{C}$ are in crystalline state with cubic spinel crystal structure [21]. Broadening of the XRD peaks says the nano-crystalline behaviour of ferrite. The grain size of the nano-particles were calculated from the most intense peak (3 111 ) of XRD data using DebyeScherer equation.

$$
t=\frac{0.9 \lambda}{\beta \cos \theta}
$$

Lattice parameter, $\mathrm{X}$-ray density were calculated by the following equations.

$$
\begin{gathered}
a=d \sqrt{h^{2}+k^{2}+l^{2}} \\
\rho_{x}=\frac{8 M}{N a^{3}}
\end{gathered}
$$

The calculated particle size was found in the range of $17 \mathrm{~nm}$ to $52 \mathrm{~nm}$, Figure 2 shows the lattice parameter values were found to decrease from $8.472 \AA$ to $8.205 \AA$ with increasing the Al doping [22]. The lattice parameter values observed in $\mathrm{Ni}_{0.5} \mathrm{Zn}_{0.5} \mathrm{Al}_{\mathrm{x}} \mathrm{Fe}_{2-\mathrm{x}} \mathrm{O}_{4}(\mathrm{x}=0.0,0.2,0.4,0.6,0.8,1.0,1.2,1.4,1.6,1.8,2.0)$ are in good agreement with the reported values of cubic spinel ferrites [23] [24]. The decrease in the value of lattice parameters with increase in $\mathrm{Al}^{3+}$ doping can be explained on the basis of difference in their ionic radius of $\mathrm{Fe}$ and $\mathrm{Al}$ ions. (Ionic radius of $\mathrm{Al}^{3+}$ ion is $0.57 \AA$ and $\mathrm{Fe}^{3+}$ ion $0.67 \AA$ ). The decrease in the lattice parameter is due to the replacement of $\mathrm{Fe}^{3+}$ ion by $\mathrm{Al}^{3+}$ ion of a smaller ionic radius [25]. Similar behavior of lattice constant was reported in the literature [26].

Using the values of lattice constant ( $a$ ) and the distance between magnetic ions (ion jump lengths) available in tetrahedral ( $A$-site), octahedral ( $B$-site) i.e. " $L_{A}$ " and " $L_{B}$ " respectively was calculated by using the following relations [27].

$$
\begin{aligned}
L_{A} & =\left(\sqrt{\frac{3}{4}}\right) a \\
L_{B} & =\left(\sqrt{\frac{2}{4}}\right) a
\end{aligned}
$$

where, $a$ = lattice constant.

Calculated values of ion jump lengths $\left(L_{A}\right.$ and $\left.L_{B}\right)$ are given in Table 1, which shows that ion jump lengths decreased by the increasing the $\mathrm{Al}$ content. The ion jump lengths $\left(L_{A}\right.$ and $\left.L_{B}\right)$ are directly proportional to lattice constant $(a)$ value. Hence, it was observed that the ion jump lengths decreased with the increasing of the $\mathrm{Al}$ concentration.

Figure 3 represents the complete samples (total $=11)$ SEM images. SEM images of compositions $(\mathrm{x}=1.6$ and $\mathrm{x}=2.0$ ) have somehow been reversed.

Figure 4 shows the EDX pattern of $\mathrm{Ni}_{0.5} \mathrm{Zn}_{0.5} \mathrm{Al}_{x} \mathrm{Fe}_{2-\mathrm{x}} \mathrm{O}_{4}(\mathrm{x}=1.0)$, the peaks of the elements Ni, $\mathrm{Zn}, \mathrm{Al}, \mathrm{Fe}$ and $\mathrm{O}$ were observed on the EDX image and all samples confirmed the homogeneous mixing of the $\mathrm{Ni}, \mathrm{Zn}, \mathrm{Fe}$, $\mathrm{Al}$ and $\mathrm{O}$ atoms in pure and doped ferrites. The observed composition is almost equal to that of the sample produced by stoichiometric calculations without precipitating cations [28].

FTIR spectra for the compositions of $\mathrm{Ni}_{0.5} \mathrm{Zn}_{0.5} \mathrm{Al}_{\mathrm{x}} \mathrm{Fe}_{2-\mathrm{x}} \mathrm{O}_{4}(\mathrm{x}=0.0,0.2,0.4,0.6,0.8,1.0,1.2,1.4,1.6,1.8,2.0)$ have been taken using in the range of $500-4000 \mathrm{~cm}^{-1}$. Figure 5 shows the higher frequency band and lower frequency band are assigned to the tetrahedral and octahedral complexes [29] [30]. The FTIR image is reported 


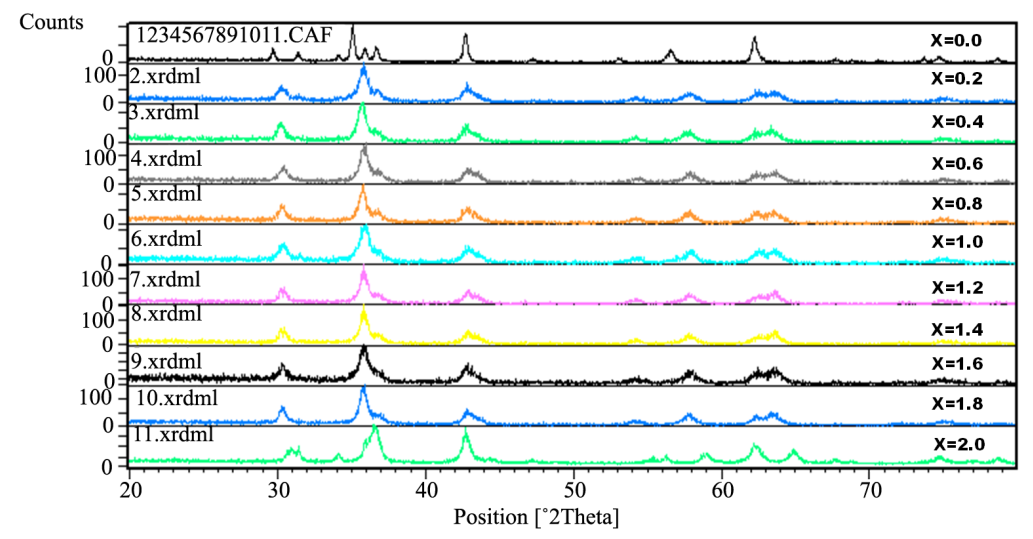

Figure 1. X-ray diffraction pattern of $\mathrm{Ni}_{0.5} \mathrm{Zn}_{0.5} \mathrm{AlxFe}_{2-\mathrm{x}} \mathrm{O}_{4}(\mathrm{x}=0.0,0.2,0.4$, $0.6,0.8,1.0,1.2,1.4,1.6,1.8,2.0)$ ferrite nano-particles.
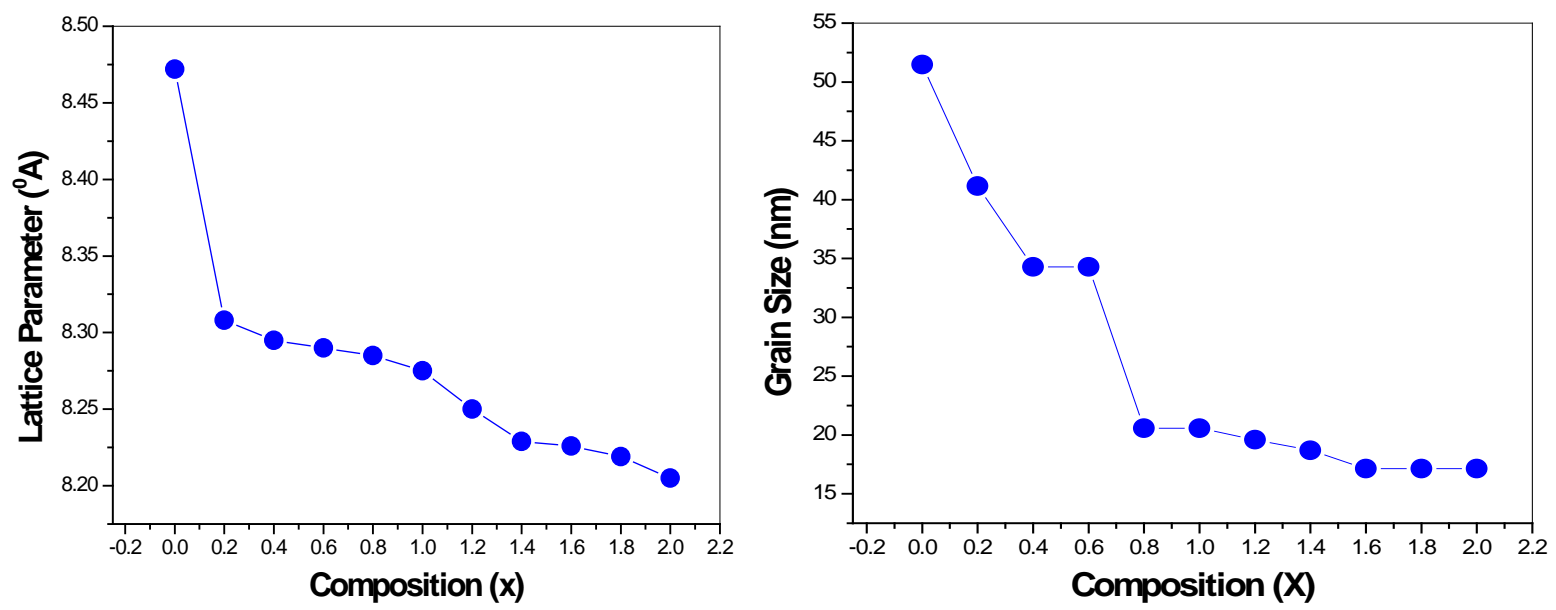

Figure 2. Lattice parameter, grain size with $\mathrm{Al}$ composition graphs of $\mathrm{Ni}_{0.5} \mathrm{Zn}_{0.5} \mathrm{Al}_{\mathrm{x}} \mathrm{Fe}_{2-\mathrm{x}} \mathrm{O}_{4}(\mathrm{x}=0.0,0.2,0.4,0.6,0.8,1.0$, $1.2,1.4,1.6,1.8,2.0)$ ferrite nano-particles.

the formation of spinel structure and the strong absorption bands around $600 \mathrm{~cm}^{-1}$ and $400 \mathrm{~cm}^{-1}$ which are characteristic of the tetrahedral and octahedral metal ions have been reported in the literature [31].

It is observed that the size of the particle is decreased with the Al content and for the composition $\mathrm{X}=2$ the particle size is found lowest. Figure 6 shows the $\mathrm{M}-\mathrm{H}$ curves of $\mathrm{Ni}_{0.5} \mathrm{Zn}_{0.5} \mathrm{Al}_{\mathrm{x}} \mathrm{Fe}_{2-\mathrm{x}} \mathrm{O}_{4}(\mathrm{x}=0.0,0.2,0.4,0.6,0.8$, $1.0,1.2,1.4,1.6,1.8,2.0)$ ferrite nanoparticles. The magnetization curves display narrow hysteresis for all the compositions except the composition $X=2.0$ showed no hysteresis and both retentivity and coercivity parameters are almost found zero. The results reveal that the saturation magnetization of the nanoparticles decreased, while the coercivity kept at almost near zero value with increasing Al substitution. The saturation has not been reached even at its maximum applied field of $20 \mathrm{kOe}$. This phenomenon can be as signed to the fact that the magnitude of the magnetic field required to reach saturation magnetization depends on the size of the particles [32]. It is also clear that, all the compositions exhibited narrow loops, with a behaviour characteristic of soft magnetic materials (easy magnetization and demagnetization) [33]-[35]. All compositions exhibit low magnetization values and small coercive fields. The low values of magnetization can be explained on the basis of coreshell model which explains that the finite size effect of then a no particles leads to an on collinearity or canting of spins on their surface which there by reduces the magnetization. The decrease in the magnetization value may also be attributed to the presence of $\mathrm{Al}^{3+}$ paramagnetic ions with down-spin configuration instead of $\mathrm{Fe}^{3+}$ cations with up-spin configuration in the octahedral sites.

The hysteresis curves of $\mathrm{Ni}_{0.5} \mathrm{Zn}_{0.5} \mathrm{Al}_{\mathrm{x}} \mathrm{Fe}_{2-\mathrm{x}} \mathrm{O}_{4}(\mathrm{x}=2.0)$ ferrite nanoparticles are shown in Figure 7. The magnetization curves display no hysteresis and both retentivity and coercivity parameters are found almost zero and the ferrimagnetic hysteresis seems to have disappeared at room temperature. Verdes et al. [36] mentioned that 

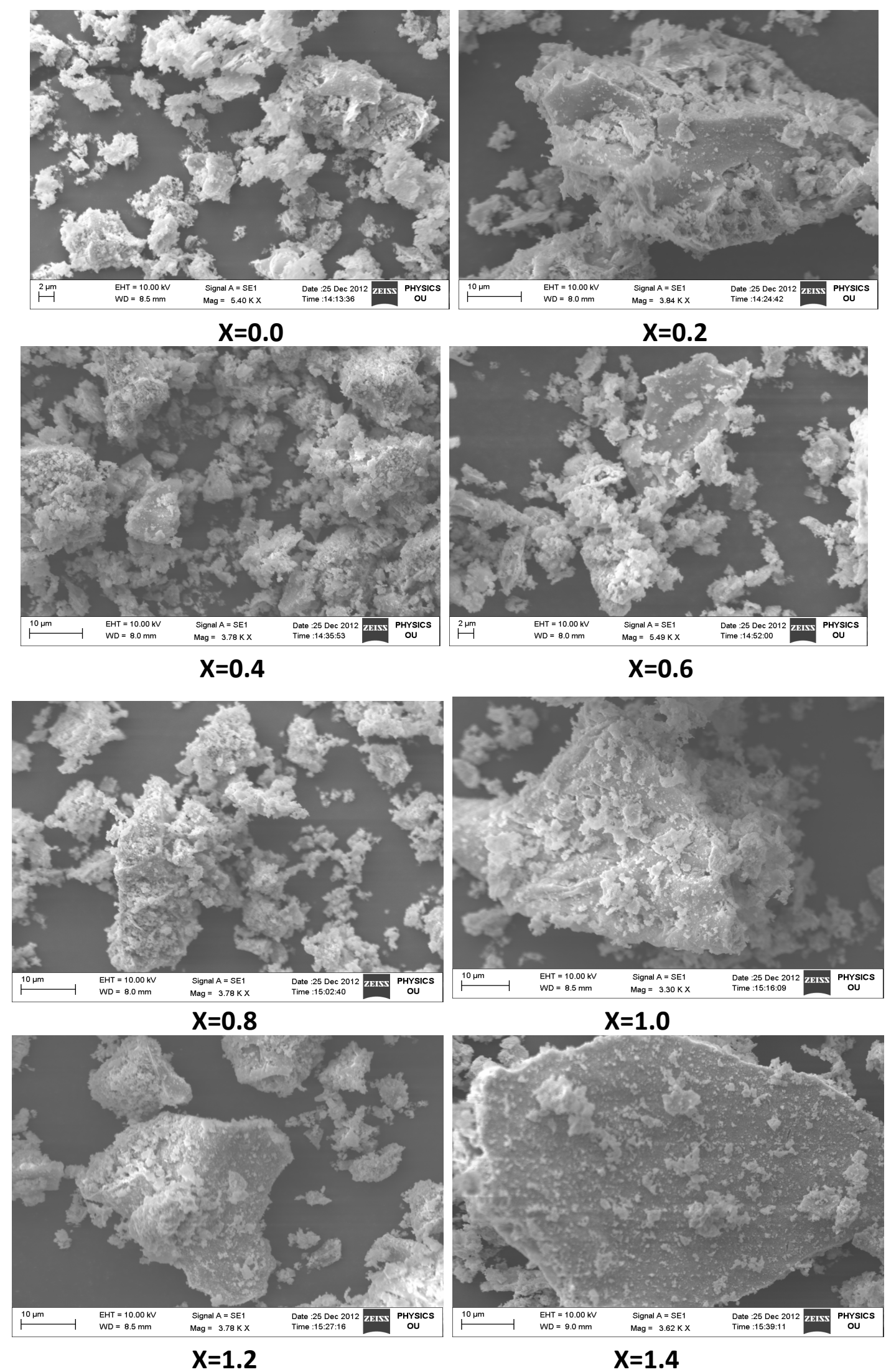


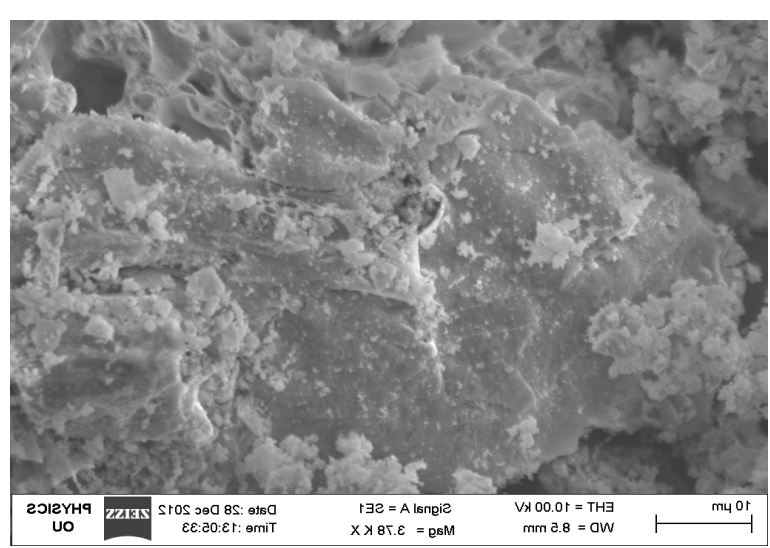

$X=1.6$

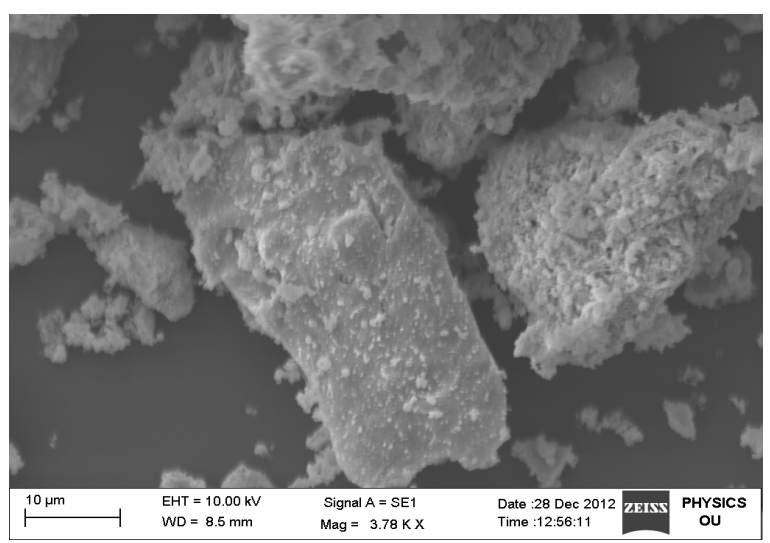

$X=1.8$

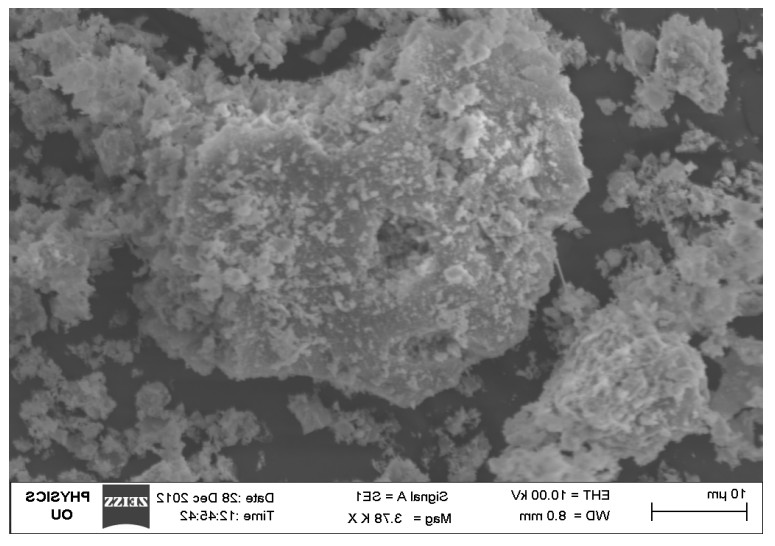

$\mathbf{X}=\mathbf{2 . 0}$

Figure 3. SEM images of $\mathrm{Ni}_{0.5} \mathrm{Zn}_{0.5} \mathrm{Al}_{x} \mathrm{Fe}_{2-\mathrm{x}} \mathrm{O}_{4}(\mathrm{x}=0.0,0.2,0.4,0.6,0.8,1.0,1.2,1.4,1.6,1.8,2.0)$ ferrite nano-particles.

Table 1. Structural properties of $\mathrm{Ni}_{0.5} \mathrm{Zn}_{0.5} \mathrm{Al}_{x} \mathrm{Fe}_{2-\mathrm{x}} \mathrm{O}_{4}(\mathrm{x}=0.0,0.2,0.4,0.6,0.8,1.0,1.2,1.4,1.6,1.8,2.0)$ ferrite nanoparticles.

\begin{tabular}{|c|c|c|c|c|c|}
\hline $\begin{array}{c}\text { Composition } \\
\text { (x) }\end{array}$ & $\begin{array}{c}\text { Lattice parameter } \\
\text { (§̊) }\end{array}$ & $\begin{array}{c}\mathrm{X} \text {-ray density } \\
\left(\mathrm{g} / \mathrm{cm}^{3}\right)\end{array}$ & $\begin{array}{l}\text { Grain size } \\
\quad(\mathbf{n m})\end{array}$ & $\begin{array}{l}L_{A} \\
(\AA)\end{array}$ & $\begin{array}{l}L_{B} \\
(\AA)\end{array}$ \\
\hline $\mathrm{x}=0.0$ & 8.472 & 5.373 & 51.47 & 3.668 & 2.994 \\
\hline $\mathrm{x}=0.2$ & 8.308 & 5.263 & 41.16 & 3.597 & 2.936 \\
\hline$x=0.4$ & 8.295 & 5.192 & 34.29 & 3.591 & 2.932 \\
\hline $\mathrm{x}=0.6$ & 8.290 & 5.138 & 34.29 & 3.589 & 2.930 \\
\hline $\mathrm{x}=0.8$ & 8.285 & 5.013 & 20.58 & 3.587 & 2.928 \\
\hline$x=1.0$ & 8.275 & 4.896 & 20.58 & 3.583 & 2.925 \\
\hline $\mathrm{x}=1.2$ & 8.250 & 4.804 & 19.60 & 3.572 & 2.916 \\
\hline $\mathrm{x}=1.4$ & 8.229 & 4.703 & 18.70 & 3.563 & 2.908 \\
\hline$x=1.6$ & 8.226 & 4.570 & 17.15 & 3.561 & 2.907 \\
\hline $\mathrm{x}=1.8$ & 8.219 & 4.444 & 17.15 & 3.558 & 2.905 \\
\hline$x=2.0$ & 8.205 & 4.328 & 17.15 & 3.552 & 2.900 \\
\hline
\end{tabular}




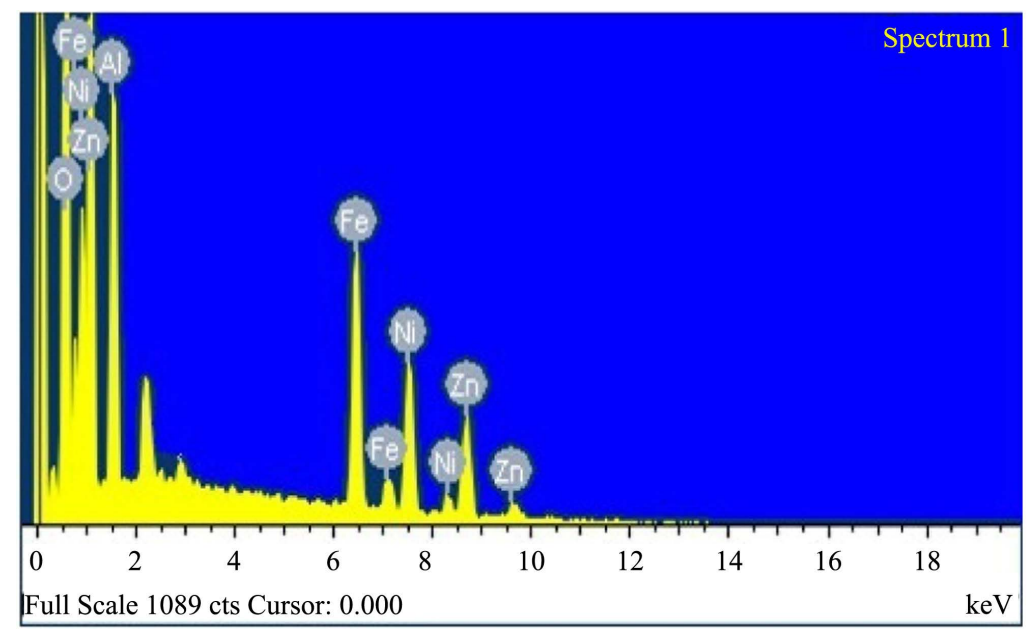

Figure 4. EDX pattern of $\mathrm{Ni}_{0.5} \mathrm{Zn}_{0.5} \mathrm{Al}_{x} \mathrm{Fe}_{2-\mathrm{x}} \mathrm{O}_{4}(\mathrm{x}=1.0)$ ferrite nano-particles.

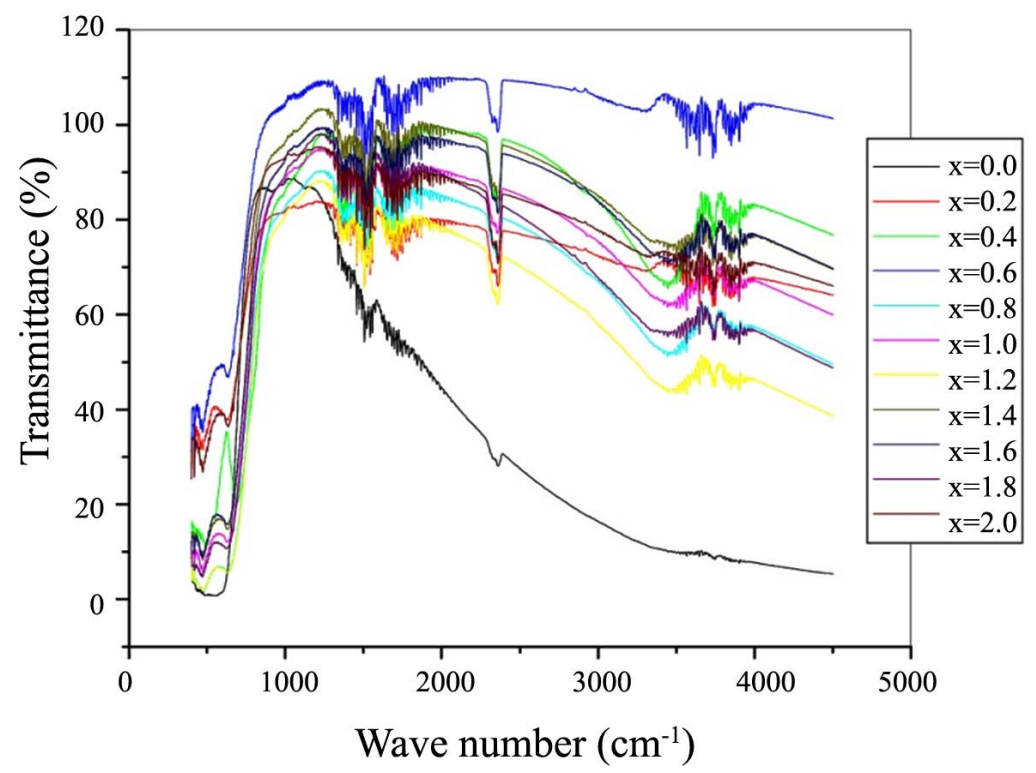

Figure 5. FTIR of $\mathrm{Ni}_{0.5} \mathrm{Zn}_{0.5} \mathrm{Al}_{\mathrm{x}} \mathrm{Fe}_{2-\mathrm{x}} \mathrm{O}_{4}(\mathrm{x}=0.0,0.2,0.4,0.6,0.8,1.0,1.2,1.4$, $1.6,1.8,2.0)$ ferrite nano-particles.

the low values of coercivity have been attributed to the particle-particle interactions among the nano-crystals owing to their extremely small size. The proximity of particles has a large effect on the hysteresis as they either become increasingly exchange coupled or show magnetostatic interactions with decreasing distance between the particles [37]. In other words, such magnetic behavior can be expressed in terms of superparamagnetism.

\section{Conclusion}

We successfully synthesized and characterized the $\mathrm{Ni}_{0.5} \mathrm{Zn}_{0.5} \mathrm{Al}_{x} \mathrm{Fe}_{2-\mathrm{x}} \mathrm{O}_{4}(\mathrm{x}=0.0,0.2,0.4,0.6,0.8,1.0,1.2,1.4$, 1.6, 1.8, 2.0) ferrite nanoparticles using sol-gel auto combustion technique. XRD and the FTIR pattern showed that all the compositions were formed into single phase cubic spinel structure. The lattice parameters and the grain size were found decreasing with $\mathrm{Al}$ content. The SEM images showed the crystalline structure where as EDX patterns confirmed the compositional formation of the synthesized samples. It is observed that particle size is decreased with the $\mathrm{Al}$ content. For the composition $\mathrm{Ni}_{0.5} \mathrm{Zn}_{0.5} \mathrm{Al}_{x} \mathrm{Fe}_{2-\mathrm{x}} \mathrm{O}_{4}(\mathrm{x}=2.0)$, the magnetization curves display no hysteresis and both retentivity and coercivity parameters are found almost zero and such magnetic behavior can be expressed in terms of superparamagnetism. 


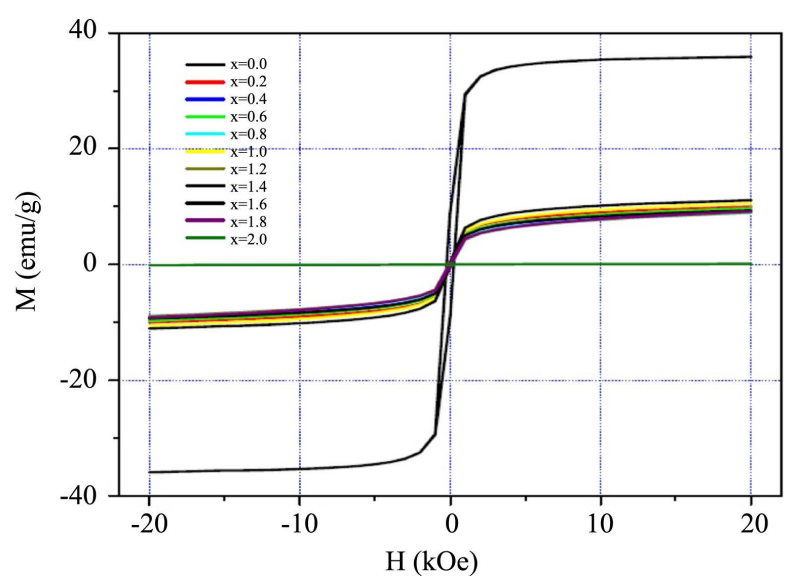

Figure 6. $\mathrm{M}$-H loops of $\mathrm{Ni}_{0.5} \mathrm{Zn}_{0.5} \mathrm{Al}_{\mathrm{x}} \mathrm{Fe}_{2-\mathrm{x}} \mathrm{O}_{4}(\mathrm{x}=0.0,0.2,0.4$, $0.6,0.8,1.0,1.2,1.4,1.6,1.8,2.0)$ ferrite nano-particles.

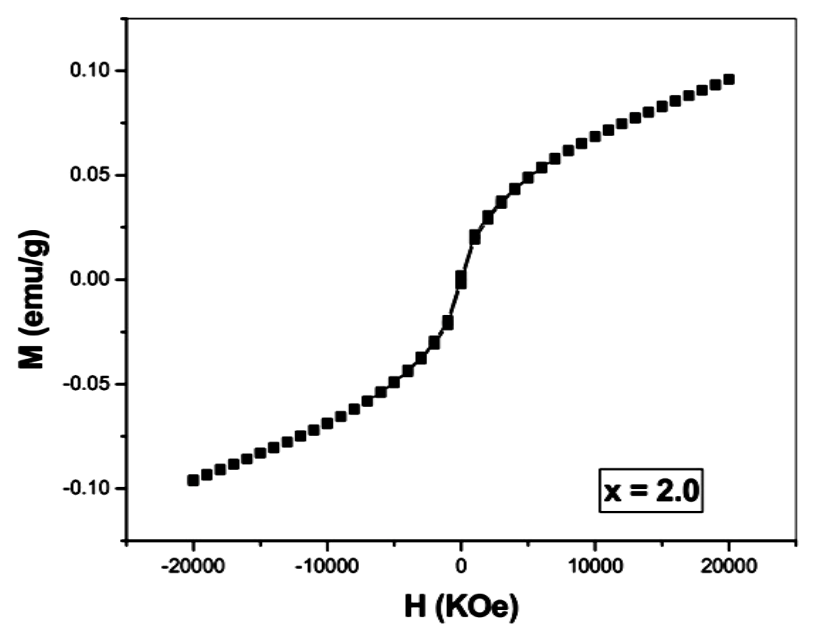

Figure 7. Composition (x) versus saturation magnetization of $\mathrm{Ni}_{0.5} \mathrm{Zn}_{0.5} \mathrm{Al}_{\mathrm{x}} \mathrm{Fe}_{2-\mathrm{x}} \mathrm{O}_{4}(\mathrm{x}=2.0)$ ferrite nano-particles.

\section{Acknowledgements}

The authors DP and PVR are grateful to the Principal, SNIST, Ghatkesar, Hyderabad for his support. The author KVK is thankful to Prof. M. Thirumala Chary, Principal, JNTUH CE, Nachupally (Kondagattu), KarimnagarDist., TS, India for his constant encouragement in bringing out this research work.

\section{References}

[1] Rashad, M.M., Elsayed, E.M., Moharam, M.M., Abou-Shahba, R.M. and Saba, A.E. (2009) Structure and Magnetic Properties of $\mathrm{Ni}_{\mathrm{x}} \mathrm{Zn}_{1-\mathrm{x}} \mathrm{Fe}_{2} \mathrm{O}_{4}$ Nanoparticles Prepared through Co-Precipitation Method. Journal of Alloys and Compounds, 486, 759-767. http://dx.doi.org/10.1016/j.jallcom.2009.07.051

[2] Krishna, K.R., Kumar, K.V., Ravindernathgupta, C. and Ravinder, D. (2012) Magnetic Properties of Ni-Zn Ferrites by Citrate Gel Method. Advances in Materials Physics and Chemistry, 2, 149-154. http://dx.doi.org/10.4236/ampc.2012.23022

[3] El-Sheikh, S.M., Rashad, M.M. and Harraz, F.A. (2013) Morphological Investigation and Magnetic Properties of Nickel Zinc Ferrite 1D Nanostructures Synthesized via Thermal Decomposition Method. Journal of Nanoparticle Research, 15, 1-11. http://dx.doi.org/10.1007/s11051-013-1967-9

[4] Rashad, M.M. and Nasr, M.I. (2012) Controlling the Microstructure and Magnetic Properties of Mn-Zn Ferrites Nanopowders Synthesized by Co-Precipitation Method. Electronic Materials Letters, 8, 325-329. http://dx.doi.org/10.1007/s13391-012-1104-4 
[5] Ravinder, D., Kumar, K.V. and Reddy, A.V.R. (2003) Preparation and Magnetic Properties of Ni-Zn Ferrite Thin Films. Materials Letters, 57, 4162-4164. http://dx.doi.org/10.1016/S0167-577X(03)00091-0

[6] Saba, A.E., Elsayed, E.M., Moharam, M.M., Rashad, M.M. and Abou-Shahba, R.M. (2011) Structure and Magnetic Properties of $\mathrm{Ni}_{\mathrm{x}} \mathrm{Zn}_{1-\mathrm{x}} \mathrm{Fe}_{2} \mathrm{O}_{4}$ Thin Films Prepared through Electrodeposition Method. Journal of Materials Science, 46, 3574-3582. http://dx.doi.org/10.1007/s10853-011-5271-8

[7] Sorescu, M., Diamandescu, L., Swaminathan, R., McHenry, M.E. and Feder, M. (2005) Structural and Magnetic Properties of NiZn and Zn Ferrite Thin Films Obtained by Laser Ablation Deposition. Journal of Applied Physics, 97, 10G105-1-10G105-3.

[8] Sorescu, M., Diamandescu, L., Peelamedu, R., Roy, R. and Yadoji, P. (2004) Structural and Magnetic Properties of NiZn Ferrites Prepared by Microwave Sintering. Journal of Magnetism and Magnetic Materials, 279, 195-201. http://dx.doi.org/10.1016/j.jmmm.2004.01.079

[9] Toledo, J.A., Valenzuela, M.A., Bosch, P., Armendáriz, H., Montoya, A., Nava, N. and Vazquez, A. (2000) Effect of $\mathrm{AI}^{3+}$ Introduction into Hydrothermally Prepared $\mathrm{ZnFe}_{2} \mathrm{O}_{4}$. Applied Catalysis A, 198, 235-245. http://dx.doi.org/10.1016/S0926-860X(99)00514-1

[10] Hashim, M., Alimuddin, Kumar, S., Shirsath, S.E., Kotnala, R.K., Shah, J. and Kumar, R. (2013) Synthesis and Characterizations of $\mathrm{Ni}^{2+}$ Substituted Cobalt Ferrite Nanoparticles. Materials Chemistry and Physics, 139, 364-374. http://dx.doi.org/10.1016/j.matchemphys.2012.09.019

[11] Patange, S.M., Shirsath, S.E., Jadhav, S.P., Hogade, V.S., Kamble, S.R. and Jadhav, K.M. (2013) Elastic Properties of Nanocrystalline Aluminum Substituted Nickel Ferrites Prepared by Co-Precipitation Method. Journal of Molecular Structure, 1038, 40-44. http://dx.doi.org/10.1016/j.molstruc.2012.12.053

[12] Zhao, L., Zhang, H., Xing, Y., Song, S., Yu, S., Shi, W., Guo, X., Yang, J., Lei, Y. and Cao, F. (2008) Studies on the Magnetism of Cobalt Ferrite Nanocrystals Synthesized by Hydrothermal Method. Journal of Solid State Chemistry, 181, 245-252. http://dx.doi.org/10.1016/j.jssc.2007.10.034

[13] Mozaffari, M., Amighian, J. and Magn, J. (2003) Preparation of Al-Substituted Ni Ferrite Powders via Mechanochemical Processing. Journal of Magnetism and Magnetic Materials, 260, 244-249.

[14] Mathew, D.S. and Juang, R.-S. (2007) An Overview of the Structure and Magnetism of Spinel Ferrite Nanoparticles and Their Synthesis in Microemulsions. Chemical Engineering Journal, 129, 51-65. http://dx.doi.org/10.1016/j.cej.2006.11.001

[15] Fawzi, A., Sheikh, A.D. and Mathe, V.L. (2010) Structural, Dielectric Properties and AC Conductivity of $\mathrm{Ni}_{(1-\mathrm{x})} \mathrm{Zn}_{\mathrm{x}} \mathrm{Fe}_{2} \mathrm{O}_{4}$ Spinel Ferrites. Journal of Alloys and Compounds, 502, $231-237$. http://dx.doi.org/10.1016/j.jallcom.2010.04.152

[16] Shahane, G.S., Kumar, A., Arora, M., Pant, R.P., Lal, K. and Magn, J. (2010) Synthesis and Characterization of Ni-Zn Ferrite Nanoparticles. Journal of Magnetism and Magnetic Materials, 322, 1015-1019.

[17] Kavas, H., Baykal, A., Toprak, M.S., Kseoglu, Y., Sertkol, M. and Aktas, B. (2009) Cation Distribution and Magnetic Properties of Zn Doped $\mathrm{NiFe}_{2} \mathrm{O}_{4}$ Nanoparticles Synthesized by PEG-Assisted Hydrothermal Route. Journal of Alloys and Compounds, 479, 49-55. http://dx.doi.org/10.1016/j.jallcom.2009.01.014

[18] Yao, C., Zeng, Q., Goya, G.F., Torres, T., Liu, J., Wu, H., Ge, M., Zeng, Y., Wang, Y. and Jiang, J.Z. (2007) ZnFe $\mathrm{O}_{4}$ Nanocrystals: Synthesis and Magnetic Properties. The Journal of Physical Chemistry C, 111, 12274-12278. http://dx.doi.org/10.1021/jp0732763

[19] Hashim, M., Alimuddin, Kumar, S., Koo, B.H., Shirsath, S.E., Mohammed, E.M., Shah, J., Kotnala, R.K., Choi, H.K., Chung, H. and Kumar, R. (2012) Structural, Electrical and Magnetic Properties of Co-Cu Ferrite Nanoparticles. Journal of Alloys and Compounds, 518, 11-18. http://dx.doi.org/10.1016/j.jallcom.2011.12.017

[20] Verma, V., Dar, M.A., Pandey, V., Singh, A., Annapoorni, S. and Kotnala, R.K. (2010) Magnetic Properties of NanoCrystalline $\mathrm{Li}_{0.35} \mathrm{Cd}_{0.3} \mathrm{Fe}_{2.35} \mathrm{O}_{4}$ Ferrite Prepared by Modified Citrate Precursor Method. Materials Chemistry and Physics, 122, 133-137. http://dx.doi.org/10.1016/j.matchemphys.2010.02.057

[21] Ghasemi, A., Ekhlasi, S. and Mousavinia, M. (2014) Effect of $\mathrm{Cr}$ and AI Substitution Cations on the Structural and Magnetic Properties of $\mathrm{Ni}_{0.6} \mathrm{Zn}_{0.4} \mathrm{Fe}_{2-\mathrm{x}} \mathrm{Cr}_{\mathrm{x} / 2} \mathrm{Al}_{\mathrm{x} / 2} \mathrm{O}_{4}$ Nanoparticles Synthesized Using the Sol-Gel Auto-Combustion Method. Journal of Magnetism and Magnetic Materials, 354,136-145. http://dx.doi.org/10.1016/j.jmmm.2013.10.022

[22] Sridhar, R., Ravinder, D. and Kumar, K.V. (2012) Synthesis and Characterization of Copper Substituted Nickel NanoFerrites by Citrate-Gel Technique. Advances in Materials Physics and Chemistry, 2, 192-199. http://dx.doi.org/10.4236/ampc.2012.23029

[23] Satar, A.A., El-Sayed, H.M., El-Shokrofy, K.M. and El-Tabey, M.M. (2005) Improvement of the Magnetic Properties of Mn-Ni-Zn Ferrite by the Non-magnetic $\mathrm{Al}^{3+}$-Ion Substitution. Journal of Applied Sciences, 5, 162-168. http://dx.doi.org/10.3923/jas.2005.162.168 
[24] Chandra, P. and Mater, J. (1987) Effect of Aluminium Substitution on Electrical Conductivity and Physical Properties of Zinc Ferrite. Journal of Materials Science Letters, 6, 651-652. http://dx.doi.org/10.1007/BF01770914

[25] Gunjal, R.P., et al. (2012) Dielectric Properties of Chromium Substituted Manganese Ferrites. International Journal of Advanced Engineering Technology, 3, 16-17.

[26] Singh, H., Kumar, A. and Yadav, K.L. (2011) Structural, Dielectric, Magnetic, Magnetodielectric and Impedance Spectroscopic Studies of Multiferroic $\mathrm{BiFeO}_{3}-\mathrm{BaTiO}_{3}$ Ceramics. Materials Science and Engineering: B, 176, 540-547.

[27] Mustafa, G., et al. (2015) Investigation of Structural and Magnetic Properties of $\mathrm{Ce}^{3+}$-Substituted Nanosized Co-Cr Ferrites for a Variety of Applications. Journal of Alloys and Compounds, 618, 428-436. http://dx.doi.org/10.1016/j.jallcom.2014.07.132

[28] Krishna, K.R., Ravinder, D., Kumar, K.V. and Lincon, C.A. (2012) Synthesis, XRD \& SEM Studies of Zinc Substitution in Nickel Ferrites by Citrate Gel Technique. World Journal of Condensed Matter Physics, 2, 153-159. http://dx.doi.org/10.4236/wjcmp.2012.23025

[29] Patil, S.A., Mahajan, V.C., Ghatage, A.K. and Lotke, S.D. (1998) Structure and Magnetic Properties of Cd and Ti/Si Substituted Cobalt Ferrites. Materials Chemistry and Physics, 57, 86-91. http://dx.doi.org/10.1016/S0254-0584(98)00202-8

[30] Labde, B.K., Sable, M.C. and Shamkuwar, N.R. (2003) Structural and Infra-Red Studies of $\mathrm{Ni}_{1+{ }_{x}} \mathrm{~Pb}_{\mathrm{x}} \mathrm{Fe}_{2-2 \mathrm{x}} \mathrm{O}_{4} \mathrm{System}_{\text {. }}$ Materials Letters, 57, 1651-1655. http://dx.doi.org/10.1016/S0167-577X(02)01046-7

[31] Waldron, R.D. (1955) Infrared Spectra of Ferrites. Physical Review, 99, 1727-1735. http://dx.doi.org/10.1103/PhysRev.99.1727

[32] Priyadharsini, P., Pradeep, A., Rao, P.S. and Chandrasekaran, G. (2009) Structural, Spectroscopic and Magnetic Study of Nanocrystalline Ni-Zn Ferrites. Materials Chemistry and Physics, 116, 207-213. http://dx.doi.org/10.1016/j.matchemphys.2009.03.011

[33] Martinez, B., Obradors, X., Balcells, L., Rouanet, A. and Monty, C. (1998) Low Temperature Surface Spin-Glass Transition in $\gamma-\mathrm{Fe}_{2} \mathrm{O}_{3}$ Nanoparticles. Physical Review Letters, 80, 181-184. http://dx.doi.org/10.1103/PhysRevLett.80.181

[34] Mozaffari, M., Manouchehri, S., Yousefi, M.H., Amighian, J. and Magn, J. (2010) The Effect of Solution Temperature on Crystallite Size and Magnetic Properties of Zn Substituted Co Ferrite Nanoparticles. Journal of Magnetism and Magnetic Materials, 322, 383-388. http://dx.doi.org/10.1016/j.jmmm.2009.09.051

[35] Costaa, A.C.F.M., Silvaa, V.J., Ferreiraa, H.S., Costab, A.A., Cornejoc, D.R., Kiminamid, R.H.G.A. and Gamaa, L. (2009) Structural and Magnetic Properties of Chromium-Doped Ferrite Nanopowders. Journal of Alloys and Compounds, 483, 655-657. http://dx.doi.org/10.1016/j.jallcom.2008.08.129

[36] Verdes, C., Thompson, S.M., Chantrell, R.W. and Stancu, A.L. (2002) Computational Model of Themagnetic and Transport Properties of Interacting Fine Particles. Physical Review B, 65, 174417. http://dx.doi.org/10.1103/PhysRevB.65.174417

[37] Mathew, D.S. and Juang, R.S. (2007) An Overview of the Structure and Magnetism of Spinel Ferrite Nanoparticles and Their Synthesis in Microemulsions. Chemical Engineering Journal, 129, 51-65. http://dx.doi.org/10.1016/j.cej.2006.11.001 